\title{
ROLE OF SHGs FINANCIAL EMPOWERMENT OF SCHEDULED CASTE WOMEN - A STUDY OF SCHEDULED CASTE RESERVED \& UNRESERVED CONSTITUENCIES OF ERSTWHILE KARIMNAGAR DISTRICT OF TELANGANA
}

\author{
G. Shankar ${ }^{1}$, Dr. K. Srinivas $2 \square$ \\ ${ }^{1}$ Research Scholar and Sr. Lecturer in Govt. Degree College, Dept of commerce, Osmania \\ University, Hyderabad, Telanagana \\ ${ }^{2}$ Assistant Professor and Addl. Controller of Examinations, Department of Commerce, Osmania \\ University-500007
}

DOI: https://doi.org/10.29121/granthaalayah.v8.i5.2020.75

Article Type: Research Article

Article Citation: G. Shankar, and Dr. K. Srinivas. (2020). ROLE OF SHGs FINANCIAL EMPOWERMENT OF SCHEDULED CASTE WOMEN - A STUDY OF SCHEDULED CASTE RESERVED \& UNRESERVED CONSTITUENCIES OF ERSTWHILE KARIMNAGAR DISTRICT OF TELANGANA. International Journal of Research -GRANTHAALAYAH, 8(5), 1-14.

https://doi.org/10.29121/granthaa layah.v8.i5.2020.75

Received Date: 18 May 2020

Accepted Date: 31 May 2020

Keywords:

Role of SHGs

Financial Empowerment

Caste Women

Unreserved Constituencies

\section{ABSTRACT}

The role of microfinance growing because it addresses the financial needs of the low-income population and it is also regarded by the policy-makers as an important instrument for financial inclusion. Microfinance brings credit, loan, savings and other essential financial services $60-90 \%$ of the global population who are too poor to be served by regular banks.

The specific objectives of the present study are to examine the patterns of income, expenditure and savings of members before and subsequent to joining of SHGs in select constituencies, to assess the perceptions of the SHG members on women empowerment before and subsequent to joining SHGs in select constituencies and to compare the perceptions of the SHG members on women empowerment of scheduled caste Women in scheduled caste Reserved and Unreserved Constituencies. The primary data was collected by administering a structured questionnaire to the primary members of SHGs sample of 200-member beneficiaries from Manakondur constituency, a reserved constituency for SC and 200 members from Karimnagar constituency an unreserved constituency were selected as respondents for the purpose of this study.

The data collected is processed and analyzed by using statistical test i.e., paired t-test was adopted. The mean score of the decision-making regarding income generation sample respondents in Manakondur stood at 3.60 and in Karimnagar stood at 4.19. This shows that the involvement in decision making regarding income generation has been improved more in Karimanagar constituency when compared to Manakondur constituency. The mean score of the repayment of credit by the sample respondents subsequent to joining SHGs in Manakondur stood at 3.46and in Karimnagar stood at 4.03. This shows that the repayment of credit has been improved more in Karimanagar constituency when compared to Manakondur constituency. Few members of a group should not be allowed to monopolize all loans. Large loans for a single borrower should be avoided. SHGs should enable the poor to decide the purpose of credit, size of the loan and repayment schedule based on viability of activity instead of leader's choice. It should also monitor the end use of credit taken by the members. 
Role of SHGs Financial Empowerment of Scheduled Caste Women - A Study of Scheduled Caste Reserved \& Unreserved Constituencies of Erstwhile Karimnagar District of Telangana

\section{INTRODUCTION}

The alleviation of poverty for a long time has remained a very complex and critical concern among the third world countries. Microfinance sector has traversed a long journey from micro savings to micro credit and then to micro enterprises and now entered the field of micro insurance, micro remittance and micro pension. The strategy involves forming small, cohesive and participative groups of the poor, encouraging them to pool their thrift regularly and using the pooled resources to make the small interest-bearing loans to beneficiaries, in the process learning the nuances of financial discipline. Bank credit then follows. It needs to be emphasized that NABARD views the promotion and bank linking of SHGs not merely as accredited program, but as a part of an overall arrangement for providing financial services to the poor in a sustainable manner and also an empowerment process for the beneficiary of these SHGs. It was in this scenario that the SHG-Bank Linkage Program was launched by NABARD in 1992, with the firm policy backup of the Reserve bank of India.

\section{OBJECTIVES OF THE STUDY}

The specific objectives of the present study are:

1) To study about the Women empowerment and SHG functioning.

2) To understand the Socio-economic conditions of SHG members of select constitutions.

3) To examine the patterns of income, expenditure and savings of members before and subsequent to joining of SHGs in select constituencies.

4) To assess the perceptions of the SHG members on women empowerment before and subsequent to joining SHGs in select constituencies.

5) To compare the perceptions of the SHG members on women empowerment of scheduled caste Women in scheduled caste Reserved and Unreserved Constituencies.

Primary Data: The primary data was collected by administering a structured questionnaire to the primary members of SHGs functioning in reserved Manakondur constituency and Karimnagar an unreserved constituency in erstwhile Karimnagar

Secondary Data: The secondary data was collected and compiled from internal records and reports of SHGs and DRDA, Journals like Economic and Political Weekly, Indian Journal of Commerce, SHADHAN and documents published by other regulating bodies etc.

Karimnagar is one of the Districts which exhibit the poverty of the State. Manakondur constituency, reserved constituency for SC and Karimnagar constituency, an unreserved constituency in erstwhile Karimnagar of Telangana State was chosen for the present study. A sample of 200-member beneficiaries from Manakondur constituency, a reserved constituency for SC and 200 members from Karimnagar constituency, an unreserved constituency were selected as respondents for the purpose of this study. The sample was selected based on Multi stage sampling method. In the next stage two Revenue Mandals were selected ad from each revenue mandal 5 villages were chosen. From each village two SHG's and from each SHG, approximately twenty beneficiaries or members of SHG's have been considered as respondents.

The woman empowerment is directly related with nation's development. The effective management and development of the abilities, potentials and skills of women are important for the economic development. Empowerment has been defined in terms of knowledge, skills, awareness and it has to be against powerful of domination and exploitation.

1) Economic Empowerment

- Poverty Eradiation

- Micro Finance

- Women in the Primary sector

- Women in the secondary sector

- Women in the secondary sector

- Support Services

2) Social Empowerment

- Education 
- Health

- Nutrition

- Housing and Shelter

- Environment

3) Political Empowerment

4) Personal Empowerment

Empowerment is based on the following five principles: namely a) Self-refinance b) Self-awareness c) Collective mobilization d) Interaction with external parties and e) Capacity building.

The empowerment is measured in terms of social and economic concepts using Gender Empowerment Measure (GEM) which is constructed using variables viz., Participation, decision-making and power over resources.

Though 200 questionnaires were served to the members of SHGs in Manakondur constituency to study the impact of them on various activities and only 178 questionnaires which are fully answered could be collected from the respondents. The questionnaires which are not returned by the respondents and which were not fully answered are not considered for analysis purpose and only those questionnaires which are fully answered were considered. Hence the study was restricted to only 178 respondents which constitute the sample base for this study.

\section{PROFILE OF RESPONDENTS FROM MANAKONDUR}

1) Marital status of respondents: An overwhelming majority (89.89 per cent) of the respondents are married. Of the remaining respondents 5.62 per cent un-married and 4.49 per cent are widowed among the total sample.

2) Educational Background of Respondents: 37.08 per cent of respondents possess secondary education, followed by 33.71 per cent are illiterates. About 22 per cent of the respondents have primary education and the remaining 6.74 per cent of the respondents possess Degree and above qualification.

3) Occupational Background of Respondents: 48.31 per cent are unemployed and 33.72 percent are selfemployed and 17 per cent of the respondents are represented by other occupations

4) Family Structure of Respondents: 71.91 per cent are represented nuclear families and 28.09 per cent comes under joint family.

5) Family-Size of Respondents: 61.80 per cent sample families have 3 and below family members, followed by families of 4 to 6 members account for 23.60 per cent. Further, 47.19 per cent of the families' have 4 to 6 children in their families and 31.46 per cent have 3 and below children in their families.

6) No. of working members in the family: 79.21 per cent of the families have two working men in their family followed by 10.11 per cent of the families have only one working member. Further, 65.17 per cent of the families have two working men followed by 19.10 per cent of the families have three working women in their family.

7) Residential status: An over whelming majority of consumers (89.89 per cent) live in their own houses and followed by 10.11 per cent residing in rental houses.

8) Family Income of respondents: 52 per cent of the respondents have income between Rs. 5,000-10,000 per month. The income of 40.45 per cent is falling between Rs. 10,000-15,000 per month. Whereas 6.74 per cent of the respondents mentioned that their income is less than Rs. 5,000 per month. Only 1.12 per cent stated that their income is Rs.15000 and above per month. The mean income of the respondents stood at Rs. 9297.75 per month.

9) Number of other earning members in the family: 71.91per cent respondents replied that there is only one other earning member in their family and in 10.11 per cent of the families have two other working members in their family.

10) Possession of Agricultural land: 69.66 per cent of the respondents do not have any agriculture land. The members who are holding less than two acre of land account for 25.84 per cent of the total sample.

11) No. of Milch animals: 59.55 per cent of the total respondents have only one cattle and 28.09 per cent of the sample is holding 2 milch animals. 
Role of SHGs Financial Empowerment of Scheduled Caste Women - A Study of Scheduled Caste Reserved \& Unreserved Constituencies of Erstwhile Karimnagar District of Telangana

\section{MEMBERSHIP IN SHGS AND OTHERS}

1) Membership in Social Organization: 60.67per cent of respondents have membership in social organizations and the remaining 39.33 per cent do not have membership in social organizations.

2) Duration of Membership in social organizations: 50.00 per cent of the respondents have 5 years and less duration of membership in social organizations and 37.04 per cent of the respondents have 5 to 10 years duration of membership in social organizations.

3) Membership in other organizations; 53.93 per cent of the respondents do not have membership in any other organizations and 42.70 per cent mentioned that they have membership in one other organization.

4) Tenure of memberships in SHGs; 49.44 per cent of the respondents have 5-8years of tenure of membership and 32.58 per cent have 8-12 years of tenure of membership in SHGs. 11.24 per cent of the respondents have more than 12 years tenure of membership in SHGs.

5) Position of respondent in SHGs:73.03 per cent of the respondents are only ordinary members in the groups. 17.98 of the respondents mentioned that they are the Treasurer / Cashier of their SHGs.

6) Purpose of joining SHG: 66.29 per cent of the respondents gave first rank to increase knowledge and awareness of members and 73.03 per cent gave second rank to better their relations with the society and officials. The purpose of fostering the neighbourhood relations has got third rank and the respondents who gave third rank stood at 66.29 per cent. 42.70 per cent gave fourth rank to meet the financial requirements of the members and 51.69 per cent gave fifth place to improve capability of members as their purpose of joining SHGs.

7) Reasons for joining SHG: 39.33 per cent have given first rank to economic independence and second rank was given to safe place to keep SHG their savings. The third place was given to access to emergency credit by 40.45 per cent of the respondents and 34.83 per cent treated SHGs joining as a additional source of income for their livelihood.

8) Advantages of joining SHGs: 70.79 per cent of the respondents opined that it is source of savings for them and gave first rank to it. 76.40 per cent of the respondents mentioned that the major advantage of SHG joining is the easy availability of credit and it stood in second place. In the third place the respondents said that SHG membership supplements their income.

\section{OPINION ABOUT SELF-HELP TRAINING PROGRAMMES}

1) Organization of training programmes: 93.26 per cent of the cases the SHGs organize training programmes to their members and 6.74 per cent of the respondents mentioned that their groups are not conducting training programmes to them.

2) Attending training programmes: 100.00 per cent of respondents attended training programmes organized by SHGs to their members on various activities to improve their skills and knowledge on regular basis.

3) Number of training programmes attended: 71.91 per cent of the total respondents attended only one time for the training programmes organized by their SHG, 17.98 per cent of the respondents attended two times and 8.99 per cent of the respondents attended three times for the training programmes organized by their SHG.

4) Regularity in attending training programmes: A significant majority of the respondents (75.28 per cent) attended the training programmes organized by their SHG regularly and 18.00 of the respondents mentioned that they often attend the training.

\section{OPINION ABOUT SHG MEETINGS}

1) Conduction of group meetings: 61.80 per cent of the cases the SHGs conducting the group meetings fortnightly by their SHG and 13.48 per cent of the respondents mentioned that they are conducting meetings twice in a week. 


\section{G. Shankar, and Dr. K. Srinivas}

2) Regularity in attending group meeting: Significant majority of the respondents (58.43 per cent) attended the group meeting organized by their SHG regularly and 34.00of the respondents mentioned that they attend only.

3) Agenda of group meeting: 74.16 per cent of the cases the agenda of group meeting of SHGs is decided by their members and in 11.24 per cent of the cases the agenda of group meeting decided by the secretary.

4) Discussions in group meeting: 79.78 per cent of the respondents mentioned that they mostly discuss about Income generating activities and 13.48 per cent of the respondents expressed that they discuss about loan and thrift details of their members in the group meetings.

5) Decision making in group meetings: 74.16 per cent of the cases the final decision is arrived at a by the consensus of all the members and 12.36 per cent of the cases the final decision is arrived at a by the secretary of the SHG.

\section{OPINION ABOUT INCOME AND SAVINGS}

1) Opinion about Regular Income: 93.26 per cent of the respondents have regular income to meet their obligations and 6.74 per cent of the respondents mentioned that they do not have any regular source of income and finding it very difficult to meet their needs.

2) Sources of Regular Income: 6.75 per cent of the respondents are engaged in agriculture activities for their regular income and 36.14 per cent stated that wages are the source for their regular income. Further, 18.07 per cent of the respondents mentioned that SHG activities are providing regular income to them.

3) Family Expenditure: 55.06 per cent of the respondents' expenditure is below Rs. 5000 per month before joining SHG. The expenditure of 40.45 per cent of the respondents' expenditure is between Rs. 5000 and Rs. 10000 per month and only 4.49 per cent of the respondents mentioned that their expenditure is above Rs. 10000 per month prior to joining SHG. The average expenditure of the respondents prior joining SHG is Rs. 4971.91 per month.

Subsequent to joining SHG 61.24 per cent of the respondents' expenditure is between Rs. 5000 and Rs. 10000 per month. The expenditure of 24.16 per cent of the respondents' expenditure is below Rs. 5000 and 14.61 per cent of the respondents mentioned that their expenditure is above Rs. 10000 per month Subsequent to joining SHG. The average expenditure of the respondents Subsequent to joining SHG is Rs. 7022.47 per month. There is about 41 per cent increase in the expenditure of the respondents Subsequent to joining the SHG.

4) Opinion about Savings: The proportion of respondents not having saving habit prior joining SHG stood at SHG thrift (87.19 per cent), Bank deposits (79.21per cent), Chit funds ( 94.94 per cent), postal savings (85.96 per cent), LIC policies (95.51 per cent) and other means of savings stood at 81.46 per cent.

5) It is found that a significant majority of respondents are now saving their earnings in SHG thrift (95.51 per cent), Bank deposits (78.01 per cent), Chit funds (76.97 per cent), postal savings (33.15 per cent), LIC policies (21.35 per cent) and other means of savings stood at 29.21.This clearly indicates that people have started saving their earning Subsequent to joining SHG due financial literacy learnt from other members. This is a healthy symptom from economy point of view.

6) Source of Income for Savings: Majority of the respondents (65.17 per cent) are depending on family income for their savings and 32.58 per cent depend on their own income.

7) Loan taken from SHG: An overwhelming majority (98.88 per cent) of the respondents availed the loan from SHG.

8) Number of times loan taken from SHG: Majority of responds (59.55 per cent) have taken loan for only one time from SHG.

9) Loan taken from other sources: 54.49 per cent of the respondents have taken loan from other sources to meet their obligations and 45.51 per cent of the respondents mentioned that have not taken loan from any other source to meet their needs.

10) Source of loan other than SHG: 45.68 per cent of the respondents are taking loans from commercial banks, followed by 24.69 per cent mentioned that they taking loans from friends and relatives. 
Role of SHGs Financial Empowerment of Scheduled Caste Women - A Study of Scheduled Caste Reserved \& Unreserved Constituencies of Erstwhile Karimnagar District of Telangana

11) Opinion about Insurance Policy: A significant majority (79.78 per cent) does not possess insurance policies like micro insurance policy Life insurance policy (90.45), Mediclaim policy (93.26 per cent), crop insurance (97.19 per cent), and Asset insurance (94.38 per cent) and livestock insurance (84.27 per cent) prior to joining the SHGs.

12) Further the data shows that there is some improvement in the micro insurance policies and life insurance policies Subsequent to joining SHGs. The possession of these policies increased to 73.03 per cent (micro insurance) and life insurance (44.38 per cent). There is no significant improvement in case of Medi-claim policy, crop insurance, Asset insurance and livestock SHG insurance even Subsequent to joining the SHGs.

13) Source of Funds for Loan Repayment: 55.62 per cent of the respondents are depending on their family income for repayment of their loans and the remaining 44.38 per cent stated that they are repaying the loans from their own income.

\section{FINANCIAL SUSTAINABILITY AMONG MANAKONDUR RESPONDENTS}

1) Accessibility to credit: Before joining SHG, 52.81 per cent of respondents neither agree nor disagree and 35.96 per cent of respondents agree with the statement of accessibility to credit. Whereas subsequent to joining SHG, it is observed that 25.84 per cent strongly agree and 46.07 per cent of respondents agree with the statement of improved accessibility to credit. The mean score of accessibility to credit prior joining the SHGs in Manakondur stood at 3.22 and the mean score of subsequent to joining the SHGs at 3.93. This shows that their accessibility to credit has been improved more subsequent to joining SHGs.

2) Contribution towards family expenditure: Prior joining SHG, regarding contribution towards family expenditure 41.57 per cent of respondents neither agree nor disagree and 29.22 per cent of respondents agree with the statement. Whereas subsequent to joining SHGs, 27.72 per cent strongly agree and 50.56 per cent of respondents agree with the statement of contribution towards family expenditure. The mean score of contribution towards family expenditure prior to joining the SHGs in Manakondur stood at 3.00and the mean score of subsequent to joining the SHGs at 3.96 shows the improved contribution towards family expenditure.

3) Capacity to save regularly: About capacity to save regularly prior joining SHGs, 41.57 per cent of respondents neither agree nor disagree and 29.22 per cent of respondents agree with the statement. Whereas subsequent to joining the SHGs, 21.35 per cent strongly agree and 21.35 per cent of respondents agree with the statement of improved capacity to save regularly. The mean score of capacity to save regularly prior joining the SHGs in Manakondur stood at 2.68and the mean score of subsequent to joining the SHGs at 3.64 shows the enhanced capacity to save regularly.

4) Capacity to make profitable investments: The capacity to make profitable investments prior joining SHG, 41.57 per cent of respondents neither agree nor disagree with statement followed by 31.46 per cent of respondents disagree with the statement. Whereas, the data relating to the capacity to make profitable investments subsequent to joining SHG shows that 13.48 per cent strongly agree and 33.71 per cent of respondents agree with the statement of improved capacity to make profitable investments. The mean score of capacity to make profitable investments prior joining the SHGs in Manakondur stood at 2.70 and the mean score of subsequent to joining the SHGs at 3.47 shows the better capacity to make profitable investments.

5) Capacity to meet personal expense: The data relating to the capacity to meet personal expenses prior joining SHG, 32.58 per cent of respondents neither agree nor disagree with statement followed by 20.22 per cent of respondents agree with the statement Whereas, subsequent to joining SHG 15.73 per cent strongly agree and 40.57 per cent of respondents agree with the statement of improved capacity to meet personal expenses. The mean score of capacity to meet personal expenses prior joining the SHGs in Manakondur stood at 2.70 and the mean score of subsequent to joining the SHGs at 3.70 which shows the improved capacity to meet personal expenses,

6) Timely repayment of loan: Regarding timely repayment of loan prior joining SHG, 31.46 per cent of respondents agree with statement followed by 30.34 per cent of respondents neither agree nor disagree 
with the statement. Whereas, subsequent to joining SHG 42.70 per cent agree and 14.61 per cent of respondents strongly agree with the statement of timely repayment of loan. The mean score of improved timely repayment of loan prior joining the SHGs in Manakondur stood at 2.87 and the mean score of subsequent to joining the SHGs at 43.61 which indicates the improved timely repayment of loan

7) Respectable person in family and society: About respectable person in family and society prior to joining SHG, 46.07 per cent of respondents neither agree nor disagree with statement followed by 30.34 per cent of respondents disagree with the statement. Whereas, subsequent to joining SHG 12.36 per cent strongly agree and 41.57 per cent of respondents agree with the statement of most respectable person in family and society. The mean score of respectable person in family and society prior to joining the SHGs in Manakondur stood at 2.76 and the mean score of subsequent to joining the SHGs at 3.62 which shows the improved respectable person in family and society.

8) Reduced dependence on money lenders: About reduced dependence on money lenders before joining SHG, 41.57 per cent of respondents neither agree nor disagree with statement followed by 16.85 per cent of respondents agree with the statement of. Whereas, subsequent to joining SHG, 12.36 per cent strongly agree and 33.71 per cent of respondents agree with the statement of reduced dependence on money lenders. The mean score of reduced dependence on money lenders prior to joining SHGs in Manakondur stood at 2.70 and the mean score of subsequent to joining SHGs at 3.47 which shows the reduced dependence on money lenders.

\section{SAVING HABITS OF RESPONDENTS}

- Friends and Family: Regarding savings due to compulsion of friends and family prior to joining SHG, 64.04 per cent of respondents neither agree nor disagree with statement followed by 30.34 per cent of respondents agree with the statement. Whereas subsequent to joining SHG 49.44 per cent agree and 21.35 per cent strongly agree that they save due to compulsion of friends and family. The mean score of savings due to compulsion of friends and family prior to joining SHGs in Manakondur stood at 3.28 and the mean score of subsequent to joining SHG at 3.91 which shows the improved savings due to compulsion of friends and family.

- Savings to take Loan from Group: About savings to taking loan from group prior to joining SHG, 38.20 per cent of respondents disagree and 37.08 per cent of respondents neither agree nor disagree with statement that they save to take loan from group. Whereas subsequent to joining SHG clearly indicates that 47.19 per cent agree and 25.84 per cent neither agree nor disagree that they save to a loan from group. The mean score of save to a loan from group prior to joining SHGs in Manakondur stood at 2.84 and the mean score of subsequent to joining SHGs at 3.81 reveals the better savings to a loan from group.

- Savings to provide security to get easy credit: About savings to provide security to get easy loan prior to joining SHG 38.20 per cent of respondents disagree with the statement followed by 34.83 per cent of respondents neither agree nor disagree. Whereas subsequent to joining SHG clearly indicates that 34.83 per cent strongly agree followed by 28.09 per cent agree and 21.35 neither agree nor disagree that they save to provide them as security to get easy loan. The mean score of capacity to save regularly prior to joining SHGs in Manakondur stood at 2.52 and the mean score of subsequent to joining SHGs at 3.81 which shows the improved capacity to save regularly

- Regular Savings: Regarding regularly of savings prior to joining SHG, 35.96 per cent of respondents neither agree nor disagree with statement and 24.72 per cent of respondents disagree with the statement. Whereas subsequent to joining SHG clearly indicates that 49.44 per cent strongly agree followed by 34.83 per cent agree and 10.11 per cent neither agree nor disagree that they save regularly. The mean score of capacity to save regularly prior to joining SHGs in Manakondur stood at 2.69 and the mean score of subsequent to joining SHGs at 4.28 which shows the improved capacity to save regularly.

\section{HEALTH \& HYGIENE CONDITIONS}

- Supporting My Dependents: Regarding supporting of their dependents 57.30 per cent of the respondents neither agree nor disagree and 26.97 per cent of agree with the statement before joining SHGs. Whereas subsequent to joining SHGs reveal that 41.57 per cent neither agree nor disagree and 
Role of SHGs Financial Empowerment of Scheduled Caste Women - A Study of Scheduled Caste Reserved \&

Unreserved Constituencies of Erstwhile Karimnagar District of Telangana

also agree and 14.61 per cent of the respondents strongly agree with the statement that they support their dependents. The mean score of supporting their dependents prior to joining SHGs in Manakondur stood at 3.04 and the mean score of subsequent to joining SHGs at 3.69 which shows the improved supporting of their dependents.

- Responsibility Sharing: Regarding the sharing of responsibility before joining SHG 59.55 per cent of the respondents neither agree nor disagree with the statement and 26.97 per cent disagree with the statement that they share the responsibility. Whereas subsequent to joining SHGs, 39.33 per cent of the respondents neither agree nor disagree and 31.46 agree with the statement and 23.60 strongly agree with the statement that they share the responsibility. The mean score of sharing of responsibility prior to joining SHGs in Manakondur stood at 2.87 and the mean score of subsequent to joining SHGs at 3.72 which shows the improved sharing of responsibility.

- Education to Children: Before joining SHGs, about provision of education to children, 34.83 per cent of respondents neither agree nor disagree and 33.71 per cent disagree with the statement that they provide education to their children. Whereas subsequent to joining SHGs, it was found that 40.45 per cent agree with the statement and 31.07 per cent strongly agree with the statement that they provide education to the children. The mean score of provision of education to children prior to joining SHGs in Manakondur stood at 2.62 and the mean score of subsequent to joining SHGs at 3.54 which shows the improved provision of education to children.

- Nutritional Food: Regarding nutritional food before joining SHGs, 41.57 per cent of respondents neither agree nor disagree and 21.35 per cent disagree with the statement that they provide nutritional food. Whereas subsequent to joining SHGs, it was found that 42.70 per cent agree with the statement and 20.22 per cent strongly agree with the statement that they provide nutritional food. The mean score of nutritional food prior to joining SHGs in Manakondur stood at 2.66 and the mean score of subsequent to joining SHGs at 3.80 which shows the improved nutritional food.

- Medical Care: Regarding providing medical care before joining SHGs, 33.71 per cent of respondents neither agree nor disagree and 29.21 per cent agree with the statement that they provide medical care. Whereas subsequent to joining SHGs, it was found that 39.33 per cent agree with the statement and 20.22 per cent strongly agree with the statement that they provide medical care. The mean score of providing medical care prior to joining SHGs in Manakondur stood at2.87 and the mean score of subsequent to joining SHGs at 3.72 which shows the improved providing medical care.

- Living Conditions: About proper living conditions before joining SHGs 44.94 per cent of respondents neither agree nor disagree and 20.22 per cent agree with the statement that they are having proper living conditions. Further, subsequent to joining SHGs, 49.44 per cent neither agree nor disagree with the statement and 29.21 per cent agree with the statement that they provide are having proper living conditions. The mean score of proper living conditions prior to joining SHGs in Manakondur stood at 3.34and the mean score of subsequent to joining SHGs at 3.55which shows the improved proper living conditions.

\section{INVOLVEMENT IN DECISION MAKING}

- Use family Income: Regarding involvement in decision making of usage of family income before joining SHG 48.31 per cent of respondents neither agree nor disagree and 26.97 per cent of respondents agree with the statement. Whereas subsequent to joining SHG shows that 37.08 per cent agreed with the statement and 24.72 per cent of respondents strongly agree with the statement that they use family income. The mean score of proper living conditions prior to joining SHGs in Manakondur stood at3.01 and the mean score of subsequent to joining SHGs at 3.82which shows the improved proper living conditions.

- Education and Marriage: Regarding involvement in decision making of education and marriage before joining SHGs 42.70 per cent of respondents neither agree nor disagree and 10.11 per cent agree with the statement. Whereas subsequent to joining SHGs, 35.96 per cent agree with the statement and 11.24 per cent strongly agree with the statement that they can decide about education and marriage. The mean score of decision making of education and marriage prior to joining SHGs in Manakondur stood at 2.56 


\section{G. Shankar, and Dr. K. Srinivas}

and the mean score of subsequent to joining SHGs at 3.49which shows the improved decision making of education and marriage subsequent to joining SHGs.

- Acquisition / Sale of an Asset: involvement in decision making of acquisition / sale of an asset before joining SHG, 32.58 per cent of respondents neither agree nor disagree and 25.84 per cent of respondents disagree with the statement. Whereas, subsequent to joining SHG shows that 34.83 per cent agree with the statement and 11.24 per cent of respondents strongly agree with the statement that they decide regarding acquisition / sale of an asset. The mean score of decision-making regarding acquisition / sale of an asset prior to joining SHGs in Manakondur stood at 2.66and the mean score of subsequent to joining SHGs at 3.49 which shows the better decisions regarding acquisition / Sale of an Asset.

- Construction / Maintenance of House: Before joining SHG, involvement in decision making of construction / maintenance of house, 37.08 per cent of respondents neither agree nor disagree and 26.97 per cent of respondents disagree with the statement. Whereas, subsequent to joining SHG 37.08 per cent agree with the statement and 38.20 per cent of respondents strongly agree with the statement. The mean score of decision regarding construction / maintenance of house prior to joining SHGs in Manakondur stood at 2.79 and the mean score of subsequent to joining SHGs at 3.66 which shows the improved decision-making regarding construction / maintenance of house.

- Repay Credit: Regarding repayment of credit before joining SHGs, 37.08 per cent of respondents neither agree nor disagree and 15.73 per cent agree with the statement that they can repay credit. Whereas subsequent to joining SHGs, 39.33 per cent agree with the statement and 8.99 per cent strongly agree with the statement that they can repay credit. The mean score of repayment of credit prior to joining SHGs in Manakondur stood at 2.58 and the mean score of subsequent to joining SHGs at 3.46 which shows the improved repayment of credit.

- Income Generation: The income generation before joining SHG, 58.43 per cent of respondents neither agree nor disagree and 24.72 per cent of respondents disagree with the statement that they can generate income. Whereas, subsequent to joining SHG shows that 33.71 per cent agree and 14.61 per cent of respondents strongly agree with the statement that they can generate income. The mean score of income generation conditions prior to joining SHGs in Manakondur stood at 2.98 and the mean score of subsequent to joining SHGs at 3.60 which shows the income generation has been improved due to joining of SHGs.

\section{PROFILE OF RESPONDENTS FROM KARIMNAGAR}

200 questionnaires were served to the members of SHGs in Karimnagar constituency to study the impact of SHGs on various activities and only 176 questionnaires which are fully answered could be collected from the respondents. Hence the study was restricted to only 176 respondents which constitute the sample base for this study.

1) Marital status of respondents: 81.82 per cent of the respondents are married and 10.23 per cent are widowed, 3.41 per cent un-married and 4.45 per cent are separated among the total sample.

2) Educational Background of Respondents: 31.82 per cent possess secondary education and 30.68 per cent are illiterates. About 27 per cent of the respondents have primary education.

3) Occupational Background of Respondents: Of the total sample, 40.91 percent are self employed and 28.41 per cent respondents are represented by other occupations. About 18 per cent of the respondents are unemployed.

4) Family Structure of Respondents: 59.09 per cent are represented nuclear family system and 40.91 per cent comes under joint family.

5) Family-Size of Respondents: 47.73 per cent sample families have 3and below family members and followed by families of 4 to 6 members account for 39.77 per cent. Further the data relating to children reveal that, 50.00 per cent of the families' have 4 to 6 children in their families and 31.82 per cent have 3 and below children in their families.

6) No. of working members in the family: 75.00 per cent of the families have two working men in their family followed by 15.91 per cent of the families have three working member. Further, 82.95 per cent of the families have two working women followed by 9.09 per cent of the families have three working women in their family. 
Role of SHGs Financial Empowerment of Scheduled Caste Women - A Study of Scheduled Caste Reserved \& Unreserved Constituencies of Erstwhile Karimnagar District of Telangana

7) Residential status: An over whelming majority of consumers (81.82 per cent) live in their own houses and followed by 18.18 per cent residing in rental houses.

8) Family Incomeof respondents; 47.73 per cent of the respondents have income between Rs. 10,00015,000 per month. The income of 39.77 per cent is falling between Rs. 5,000-10,000 per month. Whereas 7.95 per cent of the respondents mentioned that their income is less than Rs. 5,000 per month. The remaining 4.55 per cent stated that their income is Rs. 15000 and above per month. The mean income of the respondents stood at Rs.16250/-per month.

9) Number of other earning members in the family: 43.18 of the families, there is only one other earning member and in 31.82 per cent of the families have two other working members in their family.

10) Possession of Agricultural land: 59.09 per cent of the total respondents do not have any agriculture land. The members who are holding less than two acre of land account for 37.50 per cent of the total sample.

\section{MEMBERSHIP IN SHGs AND OTHERS}

1) Membership in Social Organisation: Majority of consumers (57.95 per cent) have membership in social organizations and the remaining 42.05 per cent do not have membership in social organizations.

2) Duration of Membership in social organizations: 54.54 per cent of the respondents have 5years and less duration of membership in social organizations and 44.32 per cent of the respondents have 5 to 10 years duration of membership in social organizations.

3) Membership in other organizations: Majority of the respondents (46.59 per cent) mentioned that they do not have membership in any other organizations and 40.91 per cent mentioned that they have membership in one other organization.

4) Tenure of memberships in SHGs: 49.44 per cent of the respondents have 5-8years of tenure of membership in SHGs and 32.58 per cent have 8-12 years of tenure of membership in SHGs.

5) Position of respondent in SHG: A significant majority of the respondents (79.55 per cent) are only ordinary members in the groups. 13.64 of the respondents mentioned that they are the Treasurer / Cashier of their SHGs.

6) Purpose of joining SHGs: 55.68 per cent of the respondents gave first rank to increase knowledge and awareness of members and 68.18 per cent gave second rank to better their relations with the society and officials. The purpose of fostering the neighborhood relations has got third rank and the respondents who gave third rank stood at 67.05 per cent.

7) Reasons for joining SHG: 39.33 per cent have given first rank to economic independence and second rank was given to safe place to keep SHG their savings. The third place was given to access to emergency credit by 40.45 per cent of the respondents

8) Advantages of joining SHG: 55.68 per cent of the respondents opined that it is source of savings for them and gave first rank to it. 56.82 per cent of the respondents mentioned that the major advantage of SHG joining is the easy availability of credit and it stood in second place.

\section{OPINION ABOUT SELF-HELP TRAINING PROGRAMMES}

1) Organization of training programmes: 78.41 per cent of the cases the SHGs organize training programmes to their members and 21.59 per cent of the respondents mentioned that their groups are not conducting training programmes to them.

2) Attending training programmes: 100.00 per cent of respondents attended training programmes on various activities organized by SHGs to improve their skills and knowledge on regular basis.

3) Number of training programmes attended: 55.68 per cent of the total respondents attended only one time and 26.14 per cent of the total respondents attended two times for the training programmes organized by their SHG.

4) Regularity in attending training programmes: 64.77 per cent of the respondents attended the training programmes organized by their SHG regularly. About 32.00 of the respondents mentioned that they often attend the training programmes. 
1) Conduction of group meetings: 55.11 per cent of the cases the SHGs conducting the group meetings fortnightly by their SHG and 17.61 per cent of the respondents mentioned that they are conducting meetings twice in a week.

2) Regularity in attending group meeting: 64.77 per cent of the respondents attended the group meeting organized by their SHG regularly and 31.82of the respondents mentioned that they attend sometimes only the group meeting.

3) Agenda of group meeting: 72.73 per cent of the cases the agenda of group meeting of SHGs is decided by their members and in 13.64 per cent of the cases the agenda of group meeting decided by the secretary.

4) Discussions in group meeting: 64.77 per cent of the respondents mentioned that they mostly discuss about Income generating activities and 23.86 per cent of the respondents expressed that they discuss about loan and thrift details of their members in the group meetings.

5) Decision making in group meetings: 63.64 per cent of the cases the final decision is arrived at a by the consensus of all the members and in 28.41 per cent of the cases the final decision is arrived at a by the secretary of the SHG.

\section{OPINION ABOUT INCOME AND SAVINGS}

1) Opinion about Regular Income: 89.77 per cent of the respondents have regular income to meet their obligations and 10.23 per cent of the respondents mentioned that they do not have any regular source of income to meet their needs.

2) Sources of Regular Income: 42.05 per cent of the respondents said that wages are the source for their regular income and 20.45 per cent stated that they are engaged in agriculture activities for their regular income.

3) Family Expenditure: 45.45 per cent of the respondents' expenditure is below Rs. 5000 per month before joining SHG. The expenditure of 43.18per cent of the respondents' expenditure is between Rs. 5000 and Rs. 10000 per month and only 11.36 per cent of the respondents mentioned that their expenditure is above Rs. 10000 per month before joining SHG. The average expenditure of the respondents before joining SHG is Rs.7000/- per month. 44.32 per cent of the respondents' expenditure is between Rs. 5000 and Rs. 10000 per month subsequent to joining SHGs. The expenditure of 37.50 per cent of the respondents' expenditure is above Rs. 10000 per month subsequent to joining SHG and 14.61 per cent of the respondents mentioned that their expenditure is below Rs. 5000. The average expenditure of the respondents subsequent to joining SHGs is Rs. $9000 /$ - per month. There is about $16 \%$ per cent increase in the expenditure of the respondents subsequent to joining SHG.

4) Opinion about Savings: The proportion of respondents not having saving habit before joining SHG stood at SHG thrift (96.59 per cent), Bank deposits (86.36per cent), Chit funds (93.18 per cent), postal savings (92.05 per cent), LIC policies ( 95.45 per cent) and other means of savings stood at 92.05 per cent. From this we can understand that majority of the respondents do not have the habit of savings before joining SHG. Further it is observed that there is lot of improvement in saving habit of the respondents subsequent to joining SHG. It is found that a significant majority of respondents are now saving their earnings in SHG thrift (94.32 per cent), Bank deposits (84.09 per cent), Chit funds (85.23 per cent), postal savings (58.52 per cent), LIC policies (56.82 per cent) and other means of savings stood at 40.91.This clearly indicates that people have started saving their earning subsequent to joining SHG due financial literacy learnt from other members.

5) Source of Income for Savings: Majority (65.91 per cent) of the respondents are depending on family income for their savings and 32.95 per cent are depending on own income for their savings.

6) Loan taken from SHG: 100.00 per cent of the respondents stated that they have availed the loan from SHG.

7) Number of times loan taken from SHG: Majority of responds (42.04 per cent) has taken loan for only one time from SHG. 28.41 per cent of the respondents mentioned that they have availed the loan for two times. 
Role of SHGs Financial Empowerment of Scheduled Caste Women - A Study of Scheduled Caste Reserved \& Unreserved Constituencies of Erstwhile Karimnagar District of Telangana

8) Loan taken from other sources: 52.27 per cent of the respondents have taken loan from other sources to meet their obligations and 47.73 per cent of the respondents mentioned that have not taken loan from any other source to meet their needs.

9) Source of loan other than SHG: 47.83 per cent of the respondents are taking loans from commercial banks, followed by 38.04 per cent mentioned that they taking loans from friends and relatives.

10) Opinion about Insurance Policy: A significant majority of the responds do not possess insurance policies like micro insurance policy (79.78 per cent), Life insurance policy (90.45), Medi claim policy (93.26 per cent), crop insurance (97.19 per cent), and Asset insurance (94.38 per cent) and livestock insurance (84.27 per cent) prior to joining SHGs. Further the data shows that there is some improvement in the micro insurance policies and life insurance policies subsequent to joining SHGs. The possession of these policies increased to 73.03 per cent (micro insurance) and life insurance (44.38 per cent).

11) Source of Funds for Loan Repayment: 53.41 per cent of the respondents are depending on their family income for repayment of their loans and the remaining 46.59 per cent stated that they are repaying the loans from their own income.

\section{FINANCIAL SUSTAINABILITY AMONG KARIMNAGAR RESPONDENTS}

1) Accessibility to credit: Before joining SHG, 63.64 per cent of respondents neither agree nor disagree and 18.18 per cent of respondents agree with the statement of accessibility to credit. Whereas subsequent to joining SHG, it is observed that 44.89 per cent strongly agree and 44.30 per cent of respondents agree with the statement of improved accessibility to credit. The mean score of accessibility to credit prior to joining SHGs in Manakondur stood at 3.01 and the mean score of subsequent to joining SHGs at 4.36. This shows that their accessibility to credit has been improved more subsequent to joining SHGs.

2) Contribution towards family expenditure: Before joining SHG, regarding contribution towards family expenditure 54.55 per cent of respondents neither agree nor disagree and 24.43 per cent of respondents agree with the statement. Whereas subsequent to joining SHGs, 66.48 per cent strongly agree and 25.00 per cent of respondents agree with the statement of contribution towards family expenditure. The mean score of contribution towards family expenditure prior to joining SHGs in Manakondur stood at 3.09and the mean score of subsequent to joining SHGs at 4.55 shows the improved contribution towards family expenditure.

3) Capacity to save regularly: About capacity to save regularly before joining SHGs, 43.73 per cent of respondents neither agree nor disagree and an equal proportion of respondents disagree with the statement. Whereas subsequent to joining SHGs, 70.45 per cent agree and 11.93 per cent of respondents strongly agree with the statement of improved capacity to save regularly. The mean score of capacity to save regularly prior to joining SHGs in Manakondur stood at 2.38 and the mean score of subsequent to joining SHGs at 3.88shows the enhanced capacity to save regularly.

4) Capacity to make profitable investments: The capacity to make profitable investments before joining SHG, 44.72 per cent of respondents disagree with statement followed by 38.07 per cent of respondents neither agree nor disagree with the statement. Whereas, the data relating to the capacity to make profitable investments subsequent to joining SHG shows that 14.20 per cent strongly agree and 36.93 per cent of respondents agree with the statement of improved capacity to make profitable investments. The mean score of capacity to make profitable investments prior to joining SHGs in Manakondur stood at 2.43 and the mean score of subsequent to joining SHGs at 3.41 shows the better capacity to make profitable investments.

5) Capacity to meet personal expense: The data relating to the capacity to meet personal expenses before joining SHG, 42.05 per cent of respondents disagree with statement followed by 32.95 per cent of respondents neither agree nor disagree with the statement Whereas, subsequent to joining SHG 14.77 per cent strongly agree and 38.07 per cent of respondents agree with the statement of improved capacity to meet personal expenses. The mean score of capacity to meet personal expenses prior to joining SHGs in Manakondur stood at 2.23 and the mean score of subsequent to joining SHGs at 3.67 which shows the improved capacity to meet personal expenses. 


\section{G. Shankar, and Dr. K. Srinivas}

6) Timely repayment of loan: Regarding timely repayment of loan before joining SHG, 49.43 per cent of respondents neither agree nor disagree with statement followed by 34.09 per cent of respondents disagree with the statement. Whereas, subsequent to joining SHG 56.25 per cent agree and 11.36 per cent of respondents strongly agree with the statement of timely repayment of loan. The mean score of improved timely repayment of loan prior to joining SHGs in Manakondur stood at 2.52 and the mean score of subsequent to joining SHGs at 3.74 which indicates the improved timely repayment of loan

7) Respectable person in family and society: About respectable person in family and society before joining SHG, 46.59 per cent of respondents disagree with statement followed by 32.95 per cent of respondents neither agree nor disagree with the statement. Whereas, subsequent to joining SHG 15.91per cent strongly agree and 43.75 per cent of respondents agree with the statement of most respectable person in family and society. The mean score of respectable person in family and society prior to joining SHGs in Manakondur stood at 2.42 and the mean score of subsequent to joining SHGs at 3.72 which shows the improved respectable person in family and society.

8) Reduced dependence on money lenders: About reduced dependence on money lenders before joining SHG, 33.52 per cent of respondents neither agree nor disagree with statement followed by 28.41 per cent of respondents disagree with the statement. Whereas, subsequent to joining SHG, 19.32 per cent strongly agree and 47.16 per cent of respondents agree with the statement of reduced dependence on money lenders. The mean score of reduced dependence on money lenders prior to joining SHGs in Manakondur stood at 2.15 and the mean score of subsequent to joining SHGs at 2.88 which shows the reduced dependence on money lenders.

\section{SAVING HABITS OF RESPONDENTS}

- Friends and Family: Regarding savings due to compulsion of friends and family prior to joining SHG, 74.43 per cent of respondents neither agree nor disagree with statement followed by 14.77 per cent of respondents disagree with the statement. Whereas subsequent to joining SHG 40.41 per cent agree and 40.91 per cent strongly agree that they save due to compulsion of friends and family. The mean score of savings due to compulsion of friends and family prior to joining SHGs in Manakondur stood at 2.88and the mean score of subsequent to joining SHGs at 4.23 which shows the improved savings due to compulsion of friends and family.

- Loan from Group: About savings to taking loan from group prior to joining SHG, 48.86 per cent of respondents disagree with the statement followed by 27.27 per cent of respondents neither agree nor disagree with statement that they save to take loan from group. Whereas subsequent to joining SHG clearly indicates that 43.75 per cent agree and 35.23 per cent strongly agree that they save to a loan from group. The mean score of save to a loan from group prior to joining SHGs in Manakondur stood at 2.63 and the mean score of subsequent to joining SHGs at 4.09reveals the better savings to a loan from group.

- Security to get easy credit: About savings to provide security to get easy loan prior to joining SHG 50.57 per cent of respondents disagree with the statement followed by 25.57 per cent of respondents neither agree nor disagree. Whereas subsequent to joining SHG clearly indicates that 65.34 per cent agree followed by 15.91 per cent strongly agree that they save to provide them as security to get easy loan. The mean score of capacity to save regularly prior to joining SHGs in Manakondur stood at 2.58and the mean score of subsequent to joining SHGs at 3.88 which shows the improved capacity to save regularly

- Regular Savings: Regarding regularly of savings prior to joining SHG, 34.66 per cent of respondents disagree with statement followed by 21.02 each per cent of respondents agree with the statement. Whereas subsequent to joining SHG clearly indicates that 58.52 per cent agree followed by 23.30 per cent disagree and 18.18 per cent strongly agree that they save regularly. The mean score of capacity to save regularly prior to joining SHGs in Manakondur stood at 2.52 and the mean score of subsequent to joining SHGs at 3.94 which shows the improved capacity to save regularly. 
Role of SHGs Financial Empowerment of Scheduled Caste Women - A Study of Scheduled Caste Reserved \& Unreserved Constituencies of Erstwhile Karimnagar District of Telangana

\section{HEALTH \& HYGIENE CONDITIONS}

- Supporting My Dependents: About, supporting of their dependents before joining SHG, 65.34 per cent of the respondents neither agree nor disagree with the statement that they support their dependents followed by 17.05 per cent of them agree with the statement. Whereas subsequent to joining SHGs reveal that 60.80 per cent agree with the statement that they support their dependents followed by 21.59 per cent of the respondents strongly agree with the statement that they support their dependents. The mean score of supporting their dependents prior to joining SHGs in Manakondur stood at 2.64 and the mean score of subsequent to joining SHGs at 3.97 which shows the improved supporting of their dependents.

- Responsibility Sharing: Regarding the sharing of responsibility before joining SHG 65.34 per cent of the respondents neither agree nor disagree with the statement followed by 22.16 per cent disagree with the statement that they share the responsibility. Whereas subsequent to joining SHGs, 42.05 per cent of the respondents strongly agree with the statement followed by 28.98 agree with the statement and 23.60 strongly agree with the statement that they share the responsibility. The mean score of sharing of responsibility prior to joining SHGs in Manakondur stood at 2.74 and the mean score of subsequent to joining SHGs at 4.06which shows the improved sharing of responsibility.

- Education to Children: Before joining SHGs, about provision of education to children, 42.61 per cent of respondents disagree with the statement followed by 41.48 per cent neither agree nor disagree with the statement that they provide education to their children. Whereas subsequent to joining SHGs, it was found that 47.16 per cent agree with the statement and 17.05 per cent strongly agree with the statement that they provide education to the children. The mean score of provision of education to children prior to joining SHGs in Manakondur stood at 2.46 and the mean score of subsequent to joining SHGs at 3.76 which shows the improved provision of education to children.

- Nutritional Food: Regarding nutritional food before joining SHGs, 40.91 per cent disagree with the statement followed by 39.20 per cent of respondents neither agree nor disagree with the statement that they provide nutritional food. Whereas subsequent to joining SHGs, it was found that 59.09 per cent agree with the statement and 31.82 per cent neither agree nor disagree with the statement that they provide nutritional food. The mean score of nutritional food prior to joining SHGs in Manakondur stood at 2.41 and the mean score of subsequent to joining SHGs at 3.72 which shows the improved nutritional food.

- Medical Care: Regarding providing medical care before joining SHGs, 52.27 per cent of respondents neither agree nor disagree with the statement followed by 26.70 per cent agree with the statement that they provide medical care. Whereas subsequent to joining SHGs, it was found that 55.11 per cent agree with the statement and 10.23 per cent strongly agree with the statement that they provide medical care. The mean score of providing medical care prior to joining SHGs in Manakondur stood at 2.27and the mean score of subsequent to joining SHGs at 3.73 which shows the improved providing medical care.

- Living Conditions: About proper living conditions before joining SHGs 58.52 per cent of respondents neither agree nor disagree with the statement followed by 19.32 per cent agree with the statement that they are having proper living conditions. Further, subsequent to joining SHGs, 44.89 per cent agree with the statement and 38.64 per cent neither agree nor disagree with the statement that they provide are having proper living conditions. The mean score of proper living conditions prior to joining SHGs in Manakondur stood at 2.67 and the mean score of subsequent to joining SHGs at 3.69 which shows the improved proper living conditions.

\section{INVOLVEMENT IN DECISION MAKING}

- Use family Income: Regarding involvement in decision making of family income before joining SHG 68.18 per cent of respondents neither agree nor disagree with statement followed by 24.43 per cent of respondents agree with the statement. Whereas subsequent to joining SHG shows that 53.98 per cent agreed with the statement and 29.55 per cent of respondents strongly agree with the statement that they use family income. The mean score of proper living conditions prior to joining SHGs in Manakondur 


\section{G. Shankar, and Dr. K. Srinivas}

stood at 2.77 and the mean score of subsequent to joining SHGs at 4.10 which shows the improved proper living conditions.

- Education and Marriage: About involvement in decision making of education and marriage before joining SHGs 64.20 per cent of respondents disagree with the statement followed by 14.20 per cent neither agree nor disagree with the statement. Whereas subsequent to joining SHGs, 35.23 per cent agree with the statement and 32.39 per cent strongly agree with the statement that they can decide about education and marriage. The mean score of decision making of education and marriage prior to joining SHGs in Manakondur stood at 2.31 and the mean score of subsequent to joining SHGs at 3.92 which shows the improved decision making of education and marriage subsequent to joining SHGs.

- Acquisition / Sale of an Asset: Involvement in decision making of acquisition / sale of an asset before joining SHG, 63.07 per cent of respondents disagree with statement followed by 17.61 per cent of respondents neither agree nor disagree with the statement. Whereas, subsequent to joining SHG shows that 44.32 per cent agree with the statement and 30.68 per cent of respondents strongly agree with the statement that they decide regarding acquisition / sale of an asset. The mean score of decision-making regarding acquisition / sale of an asset prior to joining SHGs in Manakondur stood at 2.31and the mean score of subsequent to joining SHGs at 4.01 which shows the better decisions regarding Acquisition / Sale of an Asset.

- Construction / Maintenance of House: Before joining SHG, involvement in decision making of construction / maintenance of house, 44.32 per cent of respondents disagree with statement followed by 28.41 per cent of respondents strongly disagree with the statement. Whereas, subsequent to joining SHG 39.77 per cent agree with the statement and 28.41 per cent of respondents strongly agree with the statement. The mean score of decision regarding construction / maintenance of house prior to joining SHGs in Manakondur stood at 2.06 and the mean score of subsequent to joining SHGs at 3.93 which shows the improved decision-making regarding construction / maintenance of house.

- Repay Credit: Regarding involvement in decision making of repayment of credit before joining SHGs, 56.25 per cent of respondents disagree with the statement followed by 20.45 per cent neither agree nor disagree with the statement that they can repay credit. Whereas subsequent to joining SHGs, 46.02 per cent agree with the statement and 29.32 per cent strongly agree with the statement that they can repay credit. The mean score of repayment of credit prior to joining SHGs in Manakondur stood at 2.12 and the mean score of subsequent to joining SHGs at 4.03which shows the improved repayment of credit.

- Income Generation: The involvement in decision making of income generation before joining SHG, 53.98 per cent of respondents neither agree nor disagree with statement followed by 21.02 per cent of respondents agree with the statement that they can generate income. Whereas, subsequent to joining SHG shows that 47.16 per cent agree with the statement and 39.20 per cent of respondents strongly agree with the statement that they can generate income. The mean score of income generation conditions prior to joining SHGs in Manakondur stood at 2.94 and the mean score of subsequent to joining SHGs at 4.19which shows the income generation has been improved due to joining of SHGs.

\section{FINANCIAL SUSTAINABILITY}

- Accessibility to credit: The mean score of accessibility to credit subsequent to joining SHGs by the sample respondents in Manakondur stood at 3.93 and Karimnagar stood at 4.36 which show that the accessibility to credit has been improved more in Karimanagar constituency subsequent to joining SHGs.

- Contribution towards family expenditure: The mean score of contribution towards family expenditure of sample respondents subsequent to joining SHGs in Manakondur stood at 3.96 and Karimnagar at 4.55. This shows that the capacity to save regularly has been improved more in Karimanagar constituency than Manakondur subsequent to joining SHGs.

- Capacity to save regularly: The mean score of the sample respondents regarding capacity to save regularly subsequent to joining SHGs in Manakondur stood at 3.64 Karimnagar stood at 3.88. This shows that their capacity to save regularly has been improved more in Karimanagar Constituency subsequent to joining SHGs.

- Capacity to make profitable investments: The mean score of the sample respondents about capacity to make profitable investments subsequent to joining SHGs in Manakondur stood at 3.47 and 
Role of SHGs Financial Empowerment of Scheduled Caste Women - A Study of Scheduled Caste Reserved \& Unreserved Constituencies of Erstwhile Karimnagar District of Telangana

Karimnagar stood at 3.41. This shows that their capacity to make profitable investments has been improved more in Manakondur constituency subsequent to joining SHGs.

- Capacity to meet personal expense: The mean score of the sample respondents regarding capacity to meet personal expenses subsequent to joining SHGs in Manakondur stood at 3.70 and Karimnagar stood at 3.60 regarding capacity to meet personal expenses. This shows that their capacity to meet personal expenses has been improved more in Manakondur constituency subsequent to joining SHGs.

- Timely repayment of loan: The mean score of timely repayment of loan by the sample respondents subsequent to joining SHGs in Manakondur stood at 3.61 and Karimnagar stood at 3.74 regarding timely repayment of loan. This shows that their timely repayment of loan has been improved more in Karimanagar Constituency subsequent to joining SHGs.

- Respectable person in family and society: The mean score of the sample respondents about most respectable person in family and society subsequent to joining SHGs in Manakondur stood at 3.62and in Karimnagar stood at 3.72. This shows that their most respectable person in family and society has been improved more in Karimanagar Constituency subsequent to joining SHGs.

- Reduced dependence on money lenders: The mean score of reduced dependence on money lenders the sample respondents subsequent to joining SHGs Manakondur stood at 3.47and in Karimnagar stood at 2.88. This shows that their reduced dependence on money lenders has been improved more in Manakondur constituency when compared to Manakondur constituency subsequent to joining SHGs.

\section{SAVING HABITS OF RESPONDENTS}

- Family: The mean score of saving habits due to compulsion of friends and family of the sample respondents subsequent to joining SHGs in Manakondur stood at 3.91 and Karimnagar stood at 4.23. This shows that the saving habits due to compulsion of friends and family have been improved more in Karimanagar constituency.

- Loan from Group: The mean score of saving habits due to loan of the sample respondents subsequent to joining SHGs in Manakondur stood at 3.80 and Karimnagar stood at 4.09 regarding saving habits due to loan from group. This shows that their due to loan from group has been improved more in Karimanagar Constituency subsequent to joining SHGs.

- Security to get easy credit: The mean score of saving habits due to security to get easy loan by the sample respondents subsequent to joining SHGs Manakondur stood at 3.80 and Karimnagar stood at 3.88. This shows that saving habit has been improved security to get easy loan more in Karimanagar Constituency subsequent to joining SHGs.

- Regular Savings: The mean score of saving habits due to encouragement from members of the group subsequent to joining SHGs in Manakondur stood at 4.28and in Karimnagar stood at 3.94. This shows that the saving habits due to encouragement from members of the group have been improved more in Manakondur constituency when compared to Karimanagar Constituency subsequent to joining SHGs.

- Health \& Hygiene Conditions:

- Supporting My Dependents: The mean score of support of one's dependents with respect to health and hygiene conditions subsequent to joining SHGs in Manakondur stood at 3.66 in Karimnagar stood at 3.97. This shows that their support of one's dependents with respect to health and hygiene conditions has been improved more in Karimanagar constituency.

- Responsibility Sharing: The mean score of the responsibility sharing subsequent to joining SHGs in Manakondur stood at 3.71and in Karimnagar stood at 4.06 about responsibility sharing. This shows that the sharing of responsibility has been improved more in Karimanagar Constituency subsequent to joining SHGs.

- Education to Children: The mean score of the provision of education to children by sample respondents subsequent to joining SHGs in Manakondur stood at 3.53and in Karimnagar stood at 3.76. This shows that their provision of education to children has been improved more in Karimanagar Constituency subsequent to joining SHGs.

- Nutritional Food: The mean score of the provision of nutritional food subsequent to joining SHGs in Manakondur stood at 3.79 and Karimnagar stood at 3.72. This shows that their provision of nutritional 
G. Shankar, and Dr. K. Srinivas

food has been improved more in Manakondur constituency when compared to Karimanagar Constituency subsequent to joining SHGs.

- Medical Care: The mean score of the provision of medical care subsequent to joining SHGs Manakondur stood at 3.71 and Karimnagar stood at 3.73. This shows that their provision of medical care has been improved more in Manakondur constituency when compared to Karimanagar Constituency subsequent to joining SHGs.

- Living Conditions: The mean score of the proper living conditions subsequent to joining SHGs Manakondur stood at 2.44 and Karimnagar stood at 3.69. This shows that proper living conditions more in Karimanagar Constituency subsequent to joining SHGs.

\section{PARTICIPATION IN DECISION MAKING}

- Use family Income: The mean score of the decision making of usage of family income subsequent to joining SHGs in Manakondur stood at 3.82and in Karimnagar stood at 4.10. This shows that the involvement in decision making of use family income has been improved more in Karimanagar constituency.

- Education and Marriage: The mean score of the decision making about education and marriage in Manakondur stood at 3.49and in Karimnagar stood at 3.92. This shows that the involvement in decision making about education and marriage has been improved more in Karimanagar Constituency subsequent to joining SHGs.

- Acquisition / Sale of an Asset: The mean score of involvement in decision making about acquisition/sale of an asset subsequent to joining SHGs asset in Manakondur stood at 3.49 and in Karimnagar at 4.01. This shows that their involvement in decision making about acquisition/sale of an asset has been improved more in Karimanagar constituency when compared to Manakondur constituency.

- Construction / Maintenance of House: The mean score of the decision-making regarding construction / maintenance subsequent to joining SHGs in Manakondur stood at 3.66 and Karimnagar stood at 3.93. This shows that the decision-making regarding construction / maintenance has been improved more in Karimanagar constituency subsequent to joining SHGs.

- Repayment of Credit: The mean score of the repayment of credit by the sample respondents subsequent to joining SHGs in Manakondur stood at 3.46and in Karimnagar stood at 4.03. This shows that the repayment of credit has been improved more in Karimanagar constituency when compared to Manakondur constituency.

- Income Generation: The mean score of the decision-making regarding income generation sample respondents in Manakondur stood at 3.60 and in Karimnagar stood at 4.19. This shows that the involvement in decision making regarding income generation has been improved more in Karimanagar constituency when compared to Manakondur constituency.

\section{Suggestions}

On the basis of observations from the field survey, the following suggestions are advocated for enhancing the sustainability of SHGs.

1) As observed during the survey in Manakondur constituency that, the absence of minimum educational background of the members is one of the prime obstacles for the SHGs functioning. Imparting minimum working knowledge of account keeping and micro/small business management in their local language should be imparted to the members. This will facilitate future researchers to have better access to financial data.

2) In both constituencies most of the members of SHGs are combining their personal transactions with their business of the SHGs. This severely impacted the overall indicator of sustainability, that is, the net earnings of the SHGs. Proper awareness, therefore, should be given to the groups either by the promoter agencies or by the authorities concerned. This will provide knowledge to the SHGs to distinguish businesses and personal transactions while maintaining accounts. 
Role of SHGs Financial Empowerment of Scheduled Caste Women - A Study of Scheduled Caste Reserved \& Unreserved Constituencies of Erstwhile Karimnagar District of Telangana

3) A regular training porgramme should be designed to provide overall capacity building for the SHGs, and all the stakeholders concerned should work collectively and actively in this regard.

4) Continuous support by respective promoter agencies should be made compulsory for every promoter agency for effective functioning of SHGs, which will encourage groups to handle their activities prudently.

5) Microfinance should also cover micro insurance in their loan agreement to cover future contingencies. This will boost the overall sustainability of the SHGs in the state in general and Manakondur constituency in particular.

\section{SOURCES OF FUNDING}

None.

\section{CONFLICT OF INTEREST}

None.

\section{ACKNOWLEDGMENT}

None.

\section{REFERENCES}

[1] Goyal and Goel (2012) Microfinance in India-An evaluation of Self-Help Groups Scheme. paper presented in the Third European Research Conference on Microfinance, University of Agder, Kristiansand, Norway.

[2] Mohan. K. (2011) "Role of Micro Finance in Women's Empowerment”, Journal of Management and Science, Vol. 1, No.1, Sep 2011, pp. 1-10 ISSN: 2249-1260.

[3] Reddy and Malik (2011) Microfinance Industry in India: Some Thoughts october 8, 2011 vol xlvi no 41 EPW Economic \& Political Weekly.

[4] Prabhakar (2011) Economic Development of Women through Self Help Groups in YSR District, Andhra Pradesh, India Stud Home Com Sci, 7(1): 25-34 (2013).

[5] Kumar (2010) Microfinance and Mobile Banking: The Story So Far Focus Note 62. Washington, D.C.: CGAP.

[6] Karmakar, (2010) "microfinance" in Responsible Marketing for Sustainable Business, zenon academic publishing, 31-mar-2016 - business \& economics - 206 pages.

[7] Prabhakar (2010)), Economic Development of Women through Self Help Groups in YSR District, Andhra Pradesh, India Stud Home Com Sci, 7(1): 25-34 (2013).

[8] Wallenstein (2009) The impact of microfinance on factors empowering women: Regional and Delivery Mechanisms in India's SHG Programme stanford center for international development, jan,2014.

[9] Browning and Chiappori, (1998); Duflo, (2003) Browning, Martin, and Pierre-Andre Chiappori (1998) 'Efficient intra-household allocations: A general characterization and empirical tests.'Econometrica 66(6), 1241-1278.

[10] Puhazhendhi et al (2002): SHG-Bank Linkage Programme for Rural Poor in India: An Impact Assessment. Microcredit Innovations Department, National Bank for Agriculture and Rural Development, Mumbai. 